\title{
A COMPARISON OF THE ENFORCEMENT OF CEDAW AND CRC IN MALAYSIA AND INDONESIA
}

\author{
Angel Damayanti \\ Universitas Kristen Indonesia \\ Jl. Mayjen Sutoyo, Jakarta \\ Angel.Damayanti@uki.ac.id
}

\begin{abstract}
All ASEAN member States have ratified and acceded the Convention on the Elimination of All Forms of Discrimination against Women (CEDAW) and the Convention on the Rights of the Child (CRC). As parties of both conventions, Malaysia and Indonesia should enforce specific mechanism and rules in line with CEDAW and CRC norms and standards. Yet, both countries ask reservation for several substantive and procedural matters on both conventions. This certainly restricts the enforcement on the elimination of all forms of discrimination against women and the protection of the rights of children. This is in addition to the Islamic shariah implemented in Malaysia and some regions in Indonesia as well as stereotype of women and men regarding their role in economic, social, and political. This paper will essentially show some hindrances for both governments and therefore should take some steps to reduce the limitation. The analysis will be delivered by examining all reports given by both governments to UN Commission on Women and Children, as well as shadow reports from NGOs.
\end{abstract}

Keywords: CEDAW, CRC, Reservation, Radical Feminism

\begin{abstract}
Abstrak: Semua Negara anggota ASEAN (Association of Southeast Asia Nation) telah meratifikasi dan mengaksesi Konvensi tentang Penghapusan Segala Bentuk Diskriminasi terhadap Perempuan (Convention on the Elimination of All Forms of Discrimination against Women - CEDAW) dan Konvensi tentang Hak-hak Anak (Convention on the Rights of the Child-CRC). Sebagai pihak yang meratifikasi kedua konvensi tersebut, Malaysia dan Indonesia tentu saja harus tunduk dan mengikuti aturan yang tertera di dalam konvensi tersebut. Sayangnya, Malaysia dan Indonesia mengajukan reservasi terhadap beberapa aturan dalam konvensi, baik secara substansi maupun prosedur. Hal ini tentu saja menghambat penghormatan dan pelaksanaan kedua konvensi secara menyeluruh. Hal ini semakin dipersulit dengan adanya hukum Islam yang berlaku di Malaysia dan beberapa daerah di Indonesia serta stereotipe mengenai perbedaan peran laki-laki dan perempuan yang diterapkan di dalam masyarakat kedua Negara. Paper ini akan menunjukkan beberapa kendala yang dihadapi oleh pemerintah kedua Negara dalam menerapkan aturan-aturan CEDAW dan CRC secara menyeluruh. Hal ini akan dilakukan dengan menganalisa laporan-laporan tertulis yang telah dibuat oleh pemerintah dan NGO kedua Negara.
\end{abstract}

Kata Kunci: CEDAW, CRC, Reservasi, Feminisme Radikal

\section{Pendahuluan}

All ASEAN member States have ratified and acceded the Convention on the Elimination of All Forms of Discrimination against Women (CEDAW) and the Convention on the Rights of the Child (CRC). Accordingly, ASEAN member States have obligations to enforce specific mechanism and rules in line with CEDAW and CRC norms and standards. However, the application of both human rights instruments in ASEAN states remains a problem (Linton, 2008:436). This particularly happens as some ASEAN states, namely Singapore, Malaysia, Brunei, Indonesia and Thailand enter reservations, both substantive 
and procedural, with respect to their national laws and cultural practices. This, however, results in various implementations and practice of the abovementioned human rights instruments in respective nations.

Therefore, this article aims to elaborate the practice of ASEAN member states in honouring the Conventions, particularly by exercising the implementation of CEDAW and CRC in Malaysia and Indonesia. These two countries are chosen in this paper since both have Muslims as the majority of the population. It is perceived, to some extent, that concrete practice of entire CEDAW and CRC have possible contradictions with Islam (Krivenko, 2009). The former used Islamic law as its ultimate justification to enter reservation. On the other hand, the latter was established on more secular basis and asked reservation merely on the procedural matter but restrained by certain cultural practices. The practices confirm what radical feminism says about male supremacy due to socio-cultural tradition in some states, including Malaysia and Indonesia.

Moreover, this project is interesting as the promotion ofboth, gender equality and children protection, arepart of United Nations' Millennium Development Goals (MDGs). These goals should be reached by latest of 2015, as agreed by all UN members. Therefore, this paper will examine how Malaysia and Indonesia, members of UN as well as ASEAN, implement both human rights instruments to support their MDGs achievements and deal with the challenges they encounter. In the end, this paper will also give recommendations on what can legally be done to strengthen their commitment to these Conventions.

To elaborate the above issues, this paper will be divided into three sections. First, it will briefly describe the development of CEDAW as well as CRC, and how ASEAN member states deal with these two Conventions. The second section analyzes the practice of CEDAW, particularly in Malaysia and Indonesia, and examines the difficulties as well as potential challenges in exercising the Covenant. This will be continued by the explanation of CRC implementation in both countries. In the end, this paper offers some recommendations to strengthen commitments to these Conventions in their respective national implementation.

\section{CEDAW and CRC in ASEAN States}

The Convention on the Elimination of all Forms of Discriminations Against Women (CEDAW) is an international treaty on human rights that specifically comprises the rights of women and girls. It was derived from the United Nations (UN) Declaration on Human Rights and UN Charter, particularly in Preamble par 2.In this declaration, all UN members pledged to uphold the principle of equality to every human being, as well as inadmissibility of discrimination. The Convention also ensures that every men and women to enjoy all economic, social, cultural, civil and political rights equally as notified in Preamble of CEDAW, par 2 and 3. This implies that the UN has undertaken positive steps to combat discrimination and violence against women, both in the public and private domain (Rehman, 2010: 514). 
The Convention was adopted by the UN General Assembly, which launched its resolution No. 34/180 (1979), on 18 December 1979. It came into force on 3 September 1981 on the thirtieth day after the deposit of the twentieth instrument of ratification, as suggested in the article 27 (1) of the Convention. The Optional Protocol to the Convention has also provided special procedures of the supervision of the compliance of states parties with this CEDAW. It was adopted by resolution A/RES/54/4 of 6 October 1999 at the fifty-fourth session of the General Assembly of the United Nations and entered into force on 22 December 2000. As of December 2007, 187 states have ratified the Convention, some of which asked reservations. Among of these are Islamic states such as Bangladesh, Brunei Darussalam, Kuwait, Malaysia, Maldives, Morocco, Pakistan, Saudi Arabia, and United Arab Emirates. Essentially, these states enter reservations as they find contradictions between the CEDAW implementation and their state Constitution, the Islamic Sharia.

On the other hand, the Convention on the Rights of the Child (CRC) is a legally binding international instrument to incorporate the full range of human rights, including civil, cultural, economic, political and social rights especially for children.Part I, Article 1 of CRC defines a child as every human being below the age of eighteen years.According to Paragraph 4, the Preamble of $\mathrm{CRC}$, children need a special convention because they need special care and protection that are different with what adults need. Therefore, in November 1989 state leaders of United Nations wanted to make sure that the world recognized children's rights. They then adopted the Children Convention through resolution No. 44/252 on 20 November 1989. The Convention came into force in September 1990. By now, 193 states have become parties to the Convention, some of which also enter reservations.

The Convention encapsulates various children's rights in 54 articles and three Optional Protocols. It comprises the basic human rights that children everywhere should have. Among of these are the right to survival, to develop to the fullest, to protection from harmful influences, abuse and exploitation, and to participate fully in family, cultural and social life. There are four core principles of the Convention, namely the principles of non-discrimination, devotion to the best interests of the child, the right to life, survival and development, and respect for the views of the child. Further, the Convention protects children's rights by setting standards in health care, education, legal, civil and social services.

In line with these women and children conventions, in 2000 all UN members have also agreed to achieve The Millennium Development Goals (MDGs). In this agreement, all governments pledged to reach eight international developmentgoalsas follow: (1) Eradicating extreme poverty and hunger, (2) Achieving universal primary education, (3) Promoting gender equality and empowering women, (4) Reducing child mortality rates, (5) Improving maternal 
health, (6) Combating HIV/AIDS, malaria, and other diseases, (7) Ensuring environmental sustainability, and (8) Developing a global partnership for development. From this document, we may say that the empowerment of women, promotion of gender equality and the protection of children's rights are part of MDGs.

To achieve their goals in empowering women to become the most effective drivers of development, all UN members have obligations to put some efforts. They direct interventions to advance gender equality include increasing primary school completion and secondary school access for girls, ensuring secure tenure of property to women, ensuring access to sexual and reproductive health services, promoting equal access to labour markets, providing the opportunity for greater representation in government decision-making bodies and protecting women from violence. Furthermore, all UN members need to ensure that all children, boys and girls have access equally to education at all levels. In this case, parents and communities should be able to hold their schools accountable while governments improve curricula, educational quality and mode of delivery; build human resource and infrastructure capacity, where needed; and institute incentives for bringing vulnerable children to school, including the elimination of user fees.

All ASEAN state-members have participated in these women's and children's rights Conventions. Yet, some states ask reservations for both instruments. According to Article 2.1 (d) of Vienna Convention on the Law of Treaties, reservation means a unilateral statement, however phrased or named, made by a State, when signing, ratifying, accepting, approving or acceding to a treaty, whereby it purports to exclude or to modify the legal effect of certain provisions of the treaty in their application to that State.This confirms that ASEAN states at least performs goodwill to show their commitment to International rule of Law and signals to their citizen that their government are in line with international principles although they ask reservation for several articles.

The reservation made by some ASEAN states, are divided into substantive and procedural matters. Brunei, Malaysia, Singapore and Thailand are among the countries that enter reservations at substantive articles of the CEDAW convention. Brunei expresses reservation on Articles 2, 9 and 29 (1), Malaysia on Articles 5(a), 7(b), 9(2), 16(1a), 16(1c), 16(1d) and 16(2), Singapore on Articles 2, 9 and 1, while Thailand on Article 16. (Dairiam, 2003) The rest of ASEAN states, such as Indonesia, Myanmar and Vietnam, enter reservation more on the procedural matter, as stated particularly in Article 29 (1).

Article 16 is the common provision that the reservation-proposed countries have difficulties with. This article substantially deals with equality in marriage and family relations and specifies certain rights, as mentioned in paragraph 1 and 2. Paragraph 1 comprises (a) the right to enter into marriage, (b) right to choose a spouse and to enter into marriage with free and full consent, (c) rights and responsibilities during marriage and its dissolution; (d) rights and responsibilities as parents in relating to their children; (e) 
rights to decide on the number and spacing of their children; (f) rights and responsibilities with regard to guardianship, trusteeship and adoption of children; (g) right to choose a family name, a profession and an occupation; (h) right to ownership, acquisition, management, administration, enjoyment and disposition of property. Paragraph 2 comprises the right to abolition of child marriage, setting minimum age for marriage and registration of marriage.

Some ASEAN states also enter reservations to Children's Rights Convention (CRC). They justify reservations by using their national Constitutions and prevailing practices. Brunei, for example, expresses its reservation on the provision, which may be contrary to Brunei Constitution and principles of Islam, particularly on articles 14, 20 and 21. Indonesia, also declares that it will apply articles 1, 14, 16, 17, 21, 22 and 29 of the Convention in conformity with its Constitution. Malaysia expresses reservation with respect to articles 2, 7, 14, 28 paragraph 1 (a) and 37 of the Convention, and similarly, Singapore acceded the Convention in line with her Constitution and expressed reservation to article 28 (1) and 32.

\section{The Implementation of CEDAW in Malaysia and Indonesia}

As mentioned earlier, all ASEAN states have ratified and acceded the CEDAW as well as CRC. However, some of them express reservation to particular provisions of both Conventions, with respect to their national laws and cultural practices. This also applies to Malaysia and Indonesia, as the focus of this article. This means, all ASEAN member-states have to comply the guidance provided by the Conventions, exceptionally for those reserved-provisions. Consequently, an expert and competence committee is established to monitor states compliance. As explained in the Introduction of CEDAW, monitoring process requires State parties to submit reports outlining the status of their compliance, one year after ratification and every four years thereafter.

Under the CEDAW, the ASEAN governments have to guarantee that women are able to enjoy and exercise all human rights as well as fundamental freedoms in the political, economic, social, cultural, civil or any other field. As noted in Part 1, Article 1 of the CEDAW, this enjoyment should be carried out on the basis of equality between men and women, coupled with the principle of non-discrimination. Accordingly, as notified in Article 3, all state parties have to take "all appropriate measures, including legislation to ensure the full development and advancement of women for the purpose of guaranteeing them to exercise and enjoyment of human rights and fundamental freedoms on a basis of equality with men."

However the situation in Malaysia and Indonesia confirms what Alice Echols defines as problems of male supremacy (2003: 3). As a radical feminism supporter, Echols perceives that the relationship between men and women is marked by patriarchy as a system of power. This system organizes society into a complex of relationships based on the assertion that male supremacy oppresses women. In the case of Malaysia, its legislation, political system and cultural practices remain created unfavourable situation for women. Sharia system, to a greater extent, gives greater benefits to men over women. Similarly, 
Indonesian's socio-cultural system posits Indonesian women in a different role, facility and responsibility with men. This is in addition to Sharia law that is implemented in some area such as Aceh and Depok.

Malaysian Federal Constitution, the basic and supreme law of Malaysia, has set out basic human rights standards for the country. These include the liberty of the person (Article 5), prohibition of slavery and forced labour (Article 6), protection against retrospective criminal laws (Article 7), equality before the law (Article 8), freedom of movement (Article 9), freedom of speech, assembly and association (Article 10), freedom of religion (Article 11) and education (Article 12). In applying those freedoms, the principle of non-discrimination between men and women, as enforced by CEDAW, has also been incorporated into the Federal Constitution since August 2001, with the amendment of Article 8(2). This is reported in Malaysia's Combined initial and second periodic reports on CEDAW, 2004, paragraph 4445.The report expressly prohibits discrimination on the ground of gender. In addition, the government has also amended other laws to eliminate discrimination. This includes the Income Tax Act, Penal Code, Domestic Violence Act and Distribution Act, as mentioned in par 73.

In par 77 it is also reported that Malaysia has formulated and developed a National Policy on Women since 1989, which recognized that poverty, lack of education, culture and tradition can be major hindrances to women's progress. This policy primarily guides government policies and actions to improve the status of women and encourage gender-awareness within all federal and national institutions. The Malaysian government also confirms her simultaneous efforts to strengthen the National machineries to respect, protect and fulfill women's rights in line with CEDAW. Among of these are the Ministry of Women, Family and Community Development (MWFCD), the National Advisory on Women, InterMinisterial Committees on Women, Technical Working Groups, NGOs such as the National Council of Women Organisations (NCWO) and All Women Action Malaysia (AWAM) and Women's Service Centers to provide services such as training, counseling and information for women's programs.

Nevertheless, there are some disadvantages for protection of women's rights in Malaysia, most of which derived from its legislation and political system as well as cultural practices. The narrow interpretation of the term 'discrimination against women,' in Malaysia's legislation system has become one of the biggest hindrances. The Malaysian government practically interpreted 'discrimination against women' to mean treating women differently to men to the detriment of women. Despite her efforts to amend her Federal Constitution in 2001 and other laws, Malaysian government did not define 'discrimination against women' in accordance with Article 1 of the Convention, nor in line with the principle of equality of men and women as stated in Article 2(a). The absence of any legislation that domesticates the Convention as part of the law of Malaysia is another concern as reported by Malaysia Shadow Report (SR) in 2005. Accordingly, there is no mechanism to enable the provision of the Convention to give effect to the courts, tribunals and administrative authorities.

In relation to the reservations that have been made, Malaysian government has withdrawn some reservations and put a view to remove Articles 5(a) regarding stereotype role and 7(b) participation in 
government's policy-making. Yet, she shows unwillingness to remove reservations to Articles 9(2), 16(1) [c], [f], [g] and 16(2) relating to women's right in marriage, which are perceived not in line with the implementation of Sharia law. As far as the CEDAW Committee concerned, the reservations to Article 16 are contrary to the object and purpose of the Convention. This is in addition to the government's reluctance to ratify the CEDAW's Optional Protocol, which provides additional mechanism to ensure that women's rights are fully protected.

Further, as also reported in Malaysia NGO SR, women in Malaysia tend to be underrepresented in political, public life, and decision-making position. This is in the sense of their participation in parliament, state seats and political parties. Women face discriminations due to the implementation and lack of clarity of Malaysia's dual legal systems, the civil and Sharia law. The latter gives favour of men over women, including in the case of marriage, divorce, and inheritance. Women also remain underrepresented in the workplace and family. According to Malaysia's Combined initial and second reports on CEDAW, paragraph 8 , this is particularly due to patriarchal attitudes and deep-rooted gender stereotypes about the roles of men and women in public and private life. In addition, violence against women remains a problem in Malaysia. This is in term of domestic violence, rape, sexual harassment, and migrant domestic workers.

Similarly, Indonesian government has taken legislative measures to enforce the protection and promotion of women's rights. As mentioned in Indonesia's Combined fourth and fifth periodic reports on CEDAW, paragraph 25-28, this measure is carried out either by launching new rules of law or amending the existing ones to ensure the application of non-discrimination and equality principles in the political, economic, legal, social, cultural, education and other aspects of life. Among of these laws are the Law on Anti-Trafficking of 2007, the Victim Protection Law of 2006 and the Law on Domestic Violence of 2004, the Law No. 39 of 1999 on human rights and the amendments to the 1945 Indonesian Constitution. This is in addition to the adoption of CEDAW ratification into Indonesian Law No. 7/1984.

Furthermore, since 1999 the women's empowerment program has been set up and became an integral part of National Development Program. The Minister of Women's Empowerment takes responsibility on the program. Essentially, the government developed Gender Mainstreaming Guidelines, which facilitates the gender mainstreaming process by ministries, local government bodies and members of technical staff in their work programs. The program was established by Presidential Instruction No. 9/2000, which includes mechanisms on employment, education, justice, agriculture, cooperative, health, family planning, social welfare and environment. This program expresses appreciation from the Indonesian governmentparticularly for the adoption of two national objectives such as to promote gender equality and justice in the 2000-2009 national development plan.

Unlike Malaysia, Indonesia is a more secular basis country so that their national political system is not based on Islamic law. Therefore, Indonesia enters reservation rather on the procedural matter as stated in Article 29 (1) than the substance matters.Article 29 (1) mentions 
that "any dispute between two or more States Parties concerning the interpretation or application of the present Convention which is not settled by negotiation shall, at the request of one of them, be submitted to arbitration....”. Regarding this, Indonesia takes position that any dispute relating to the interpretation or application of the Convention may only be submitted to arbitration or to the International Court of Justice with the agreement of all the parties to the dispute.

However, as concerned by the CEDAW Committee and Indonesian National Commission on Violence against Women, there is a trend to implement Sharia law in local regulations in some regions, such as in Aceh. According to CEDAW Concluding Observations on Indonesia, par 12, the trend happens due to the process of decentralization. Sharia implementation arguably creates discrimination against women on the basis of religion. This includes the flogging punishment to women in Aceh for violating the Sharia. This is in addition to the insufficiency of the Ministry of Women Empowerment in decisionmaking and financial resources to effectively promote the advancement of women and gender equality.

Although its national political system is not based on Sharia, Indonesian women continue to find difficulties to involve in political, economic, education, public life, decision-making position, and many other fields. According to Indonesia's Combined fourth and fifth periodic reports on CEDAW, par 93, this is mainly due to socio-cultural patriarchal values and stereotypes about the roles and responsibilities of women and men that exist in the society. Traditionally, women are prevented from entering public life and political activities. Further, according to CEDAW Concluding Observations on Indonesia, Indonesia still has to manage some women-related problems such as unpreparedness of women migration workers, discrimination in the labour market, high rates in maternal and infant mortality, inaccessibility to health services in rural areas, as well as women trafficking for commercial purposes or sexual exploitation and violence against women.

As mentioned earlier, radical feminism is dedicated to eliminating the sex-class system (Echols, 2003: 6) Thus, this movement aims to challenge and overthrow patriarchy by opposing standard gender roles and oppression of women and calls for a radical reordering of society. Yet the government, in this case the government of Malaysia and Indonesia, needs to supportively create conducive situation to reorder society. A full implementation of CEDAW without reservation to its provision will support the goals. The monitoring of its enforcement through certain mechanism provided by government will uphold the principle of equality to every human being, both men and women. This applies as well to the elimination of gender discrimination. Compliance both states to this Convention will significantly reduce any form of discrimination between men and women. This will also ensure that every men and women to enjoy all economic, social, cultural, civil and political rights equally.

\section{The Implementation of CRC in Malaysia and Indonesia}

With regard to the Convention on the Rights of the Child (CRC), Malaysia has ratified it in 1995. However, ratification contained a number of reservations, particularly to articles 2, 7, 14, 28 
paragraph 1 (a) and 37, which relate to principle of non-discrimination, right to acquire a nationality, freedom of expression, thought, conscience, religion, and right to education. Like in CEDAW, the Malaysian government uses discrepancies between CRC Convention and the implementation of Sharia law in her legislation system as justification. Nonetheless, Malaysia has performed its compliance to CRC by taking three measures to protect children's rights, namely legislative, administrative and policy framework.

For legislation, Malaysia has enacted a comprehensive Child Act 2001 (Act 611), which incorporates four principles of CRC that is non-discrimination, best interest of the child, the right to life, survival and development, and respect for the views of the child. As reported in Malaysia's Initial Report on CRC, the government amended some acts such as the Education Act 1996 (Act 550), Births and Death Registration Act 1957 (Act 299), Married Women and Children Act 1950 (Act 263), Reform (Marriage and Divorce) Act 1976 (Act 164), Childcare Centre Act 1984 (Act 308), Domestic Violence Act 1994 (Act 521), and Children and Young Persons (Employment) Act 1966 (Act 350), which is aimed to protect and promote children's rights.

For administrative programs, Department of Social Welfare conducted dissemination and workshop to create greater understanding of CRC among government officers. Thus, a Child Division has been established in Department of Social Welfare since 2005. The Legal and Advocacy Division of Department of Social Welfare has also taken steps to advocate child issues. In terms of policy, Malaysian government formulated a National Plan of Action for Children Survival, Protection and Development. A coordinating Council for the Protection of Children was then established to give advise to the Minister of Women, Family and Community Development on all aspect of child protection and welfare in line with the CRC. The Council is chaired by the Minister of Women, Family and Community Development, and coordinated with the relevant Government departments, international organisations, NGOs, Human Rights Commission and Child experts.

However, as noted in CRC Concluding Observation on Malaysia, 2007, there are some critical points in the implementation of CRC in Malaysia. This is to mention the different definitions of the child, regarding their age, in the two legislations systems. This gives impact to the minimum age for marriage according to the civil and sharia law. This is in addition to the lack of coordination between the government, states and local communities in children's protection programs, lack of budget for the realization of children's rights, discrimination in access to social life, health services, education and in everyday life particularly to the indigenous and minority children in remote areas as well as gender, and relatively high number of deaths and injuries among children as a result of accidents. Children also find difficulties in the enjoyment of their rights such as freedom of expression, protection from being physically, mentally and emotionally abused, being trafficked and being exploited, sexually and economically. This happens particularly due to tradition perceptions of children as objects and as the property of parents and elders. 
Like Malaysia, Indonesia has also put efforts on legislative, administrative and policy framework to fulfill its obligation in line with CRC. Although its CRC ratification is merely domesticated through President Decree, not an Act, Indonesia has integrated the rights of the Child to the 1945 Constitution. This provides a legal basis for review of other regulations. In the meantime, several new acts concerning child's human rights have also been published, such as Act No. 39/1999 concerning human rights, Act No. 4/1997 concerning the disabled, Act No. 3/1997 concerning Juvenile Courts, Act No. 22/1997 concerning narcotics, Act No. 23/2003 on Child Protection, and Act No. 20/2003 on National Education System. This is in addition to the ratification of human rights instruments, such as the Convention against Torture and Other Cruel, Inhuman or Degrading Treatment or Punishment, the International Convention on the Elimination of All Forms of Racial Discrimination, and the International Labour Organization Minimum Age Convention.

Further, as reported in Indonesia CRC Report, 2003, Indonesia has also established various mechanisms to protect and promote children's right. This is to mention the National Program of Action for Children, the Child Protection Agency, and the Indonesian Commission for Child Protection. To set up the child protection programs, the Coordinating Minister for People's Welfare and Department of Social Affairs cooperates and coordinates with international organizations, NGOs and civil society. Sponsored by UNICEF, NGO and civil societies indeed play a central role to make the Convention widely known, through seminars, consultancies, training sessions, workshops and mass media.

Nonetheless, Indonesia continues to have problems in applying the four principles of CRC, namely non-discrimination, best interest of the child, the right to life, survival and development, and respect for the views of the child. According to CRC Concluding Observations on Indonesia, 2003, among of these are the early marriage for children, especially girls with the age of 16 , the societal discrimination against girls in many practices including education, particularly those who live in poverty, children born out of wedlock, and minority children, and children are rarely heard in the family, schools and communities. The main constraint to promote these principles is the paternalistic and feudal culture that persists in the society.

In addition, the practice of violence against children, including sexual abuse, corporal punishment in schools, in public places and in the family, remains existed. Further, the number of children exploitation, sexually and economically, remain high as there is a culture that tolerates parents to neglect their responsibilities and obligations to the child due to economic difficulties. Indonesia also faces some problem regarding the access to centers for children with disabilities, the high rate of maternal mortality, child malnutrition, children with low birth weight, infectious and diseases, lack of access to water and sanitation, child and adolescent health, including HIV/AIDS, access to education for poor families, high rates of dropout and repeat, lack of supervision of the school curricula, and the large number of children who use drugs, live on the streets and thus vulnerable to violence. 


\section{Conclusion and Recommendation}

Both Malaysia and Indonesia have ratified the women and children Conventions with some blanket reservations, substantially and procedurally. The reservations that have been made, primarily justified by Sharia and national law, coupled with the government's reluctance to domesticate the Conventions and ratify the Optional Protocols, to a greater extent restrain the implementation of both Conventions. This in in addition to cultural practices as well as stereotype of men and women's rule in private and public domain existing in both states, as concluded by radical feminism. Thus, several steps need to be taken, both nationally and regionally, to enforce the fully implementation of CEDAW and CRC.

Nationally, the Malaysian and Indonesian government need to show their commitments and political willingness in performing their compliance to the Conventions. Both states may perform their commitments, as they have to submit report to the Committee of CEDAW and CRC on approved time. This includes the commitment to reform the legislation system in accordance with the Conventions and to arrange appropriate budget to support the National program on the protection and promotion of women and children's rights. The government, certainly supported by international organizations, local NGOs, local communities and mass media, should also take necessary measures to disseminate the norms and principles enforced by the Conventions. This is important so that local and national government as well as public have well awareness on women and children's rights. This may gradually reform the cultures and existing stereotypes.

Regionally and perhaps internationally, ASEAN should establish a mechanism together with a Committee on women and children to ensure its state-parties' compliance to the principles and provisions of the Conventions. Ultimately, this regional committee should coordinate and cooperate with the UN Committee in enforcing both Conventions as well as to monitor the MDGs achievements. 


\section{Bibliographies}

\section{Books:}

Dairiam, Shanti.2003. "The Status of CEDAW Implementation in the ASEAN Countries and Selected Muslim Countries," Presented at the Roundtable Discussion on Rights and Obligations Under CEDAW, 17 March 2003, Kuala Lumpur, Malaysia, organised by the Human Rights Commission of Malaysia (SUHAKAM)

Echols,Alice. 2003.Daring to Be Bad: Radical Feminism in America, 1967-1975, Minneapolis: The University of Minnesota Press.

Linton, Suzannah. 2008. "ASEAN States, Their Reservations to Human Rights Treaties and the Proposed ASEAN Commission on Women and Children” in Human Rights Quarterly, Vol. 30,2008

Rehman, Javaid, 2010.International Human Rights Law, $2^{\text {nd }}$ edition, London: Pearson Education Limited

The 1945 United Nations Charter

The 1969 Vienna Convention on the Law of Treaties

The 1979 Convention on the Elimination of All Forms of Discrimination against Women (CEDAW), United Nations - Treaty Series, Vol. 1249

The 1989 Convention on the Rights of Children (CRC)

Yahayoui Krivenko, Ekaterina. 2009.Women, Islam and International Law: Within the Context of the Convention on the Elimination of All Forms of Discrimination Against Women, Leiden: Martinus Nijhoff Publishers

\section{Websites:}

$\begin{array}{lllll}\text { CEDAW } & \text { Concluding } & \text { Observations } & \text { on } & \text { Malaysia. }\end{array}$ http://sim.law.uu.nl/SIM/CaseLaw/uncom.nsf/fe005fcb50d8277cc12569d5003e4aaa/fc56cb8 $\underline{48775733 e c 12571950031 \mathrm{a} 010 \text { ? OpenDocument (Accessed 12/06/2012) }}$

$\begin{array}{lllll}\text { CEDAW } & \text { Concluding } & \text { Observations }\end{array}$ http://sim.law.uu.nl/SIM/CaseLaw/uncom.nsf/ 
(Accessed 12/06/2012)

CEDAW in Action: Malaysia, available from http://cedaw-seasia.org/malaysia.html (Accessed $\underline{12 / 06 / 2012)}$

CRC Concluding Observation on Malaysia. 2007. http://www2.ohchr.org/english/bodies /crc/docs/co/CRC_C_MYS_CO_1.pdf (슬

CRC Concluding Observations on Indonesia. 2004. http://sim.law.uu.nl/ $\underline{\text { SIM/CaseLaw/uncom.nsf/fe005fcb50d8277cc12569d5003e4aaa/bdee76c66160fd75c1256e2e }}$ 004294d5?OpenDocument (Accessed 22/06/2012)

MDGs Goals, Targets and Indicators, accessed from http://www.unmillenniumproject.org/goals/gti.htm

Indonesia's Combined fourth and fifth periodic reports on CEDAW. 2005. http://www.unhchr.ch/tbs/doc.nsf/0/10cbcfeeebf36c25c1257221005b97a6/\$FILE/N0540418. pdf( $($ Accessed 20/06/2012)

Indonesia's CRC Report. $200 \quad \underline{\text { http://www.law.yale.edu/rcw/rcw/jurisdictions }}$ /asse/indonesia/indon_state_report_2002.htm (Accessed 25/06/2012)

Malaysia's Combined initial and second periodic reports on CEDAW. 2004. http://cedawseasia.org/docs/malaysia/MALAYSIA_initial_secondrept_2006.pdf (Accessed 25/08//2012)

Malaysian NGO Shadow Report (SR) on CEDAW. 2005. http:/www.iwraw-ap.org/ resources/pdf/Malaysia_SR.pdf(Accessed 25/08//2012)

States' reservation on $\quad$ CEDAW. http://treaties.un.org/Pages/ $\underline{\text { ViewDetails.aspx? } \mathrm{src}=\text { TREATY\&mtdsg no=IV-8\&chapter=4\&lang=en }(\text { Accessed }}$ $\underline{01 / 07 / / 2012)}$

States' reservation on CRC http://treaties.un.org/Pages/ ViewDetails.aspx?src=TREATY\&mtdsg no=IV-11\&chapter=4\&lang=en $\quad$ (Accessed $\underline{01 / 07 / / 2012)}$

The Convention on the Rights of the Child (CRC).http://www2.ohchr.org/english/law/crc.htm

The Convention on the Rights of Child (CRC) information, in UN-Treaty Collection, http://treaties.un.org/Pages/ViewDetails.aspx?src=TREATY\&mtdsg_no=IV$\underline{11 \& \text { chapter }=4 \& \text { lang }=\text { en }(\text { Accessed } 01 / 07 / / 2012)}$

The Introduction of CEDAW. http://www.un.org/womenwatch/daw/ cedaw/text/econvention.htm\#part1(Accessed 01/07//2012) 
UN Women in Southeast Asia Region Report.http://cedaw-seasia.org/by_region.html(Accessed $\underline{01 / 07 / / 2012)}$ 